\title{
STUDI PERANCANGAN PISAU PADA MESIN PENCACAH PLASTIK MENGGUNAKAN FINITE ELEMENT ANALYSIS
}

\section{Rizqi Ilmal Yaqin ${ }^{1 *}$, Mega Lazuardi Umar ${ }^{2}$, Sigiet Haryo Pranoto ${ }^{3}$, Angger Bagus Prasetiyo ${ }^{4}$, Bambang Hari Priyambodo 5}

\author{
${ }^{1}$ Program Studi Permesinan Kapal, Politeknik Kelautan dan Perikanan Dumai \\ ${ }^{2}$ Program Studi Teknik Mesin, Politeknik Negeri Banyuwangi \\ ${ }^{3}$ Program Studi Teknik Mesin, Fakultas Sains dan Teknologi, Universitas Muhammadiyah Kalimantan \\ Timur \\ ${ }^{4}$ Jurusan Teknik Mesin, Institut Teknologi Nasional Yogyakarta \\ ${ }^{5}$ Program Studi Teknik Mesin, Sekolah Tinggi Teknologi Warga Surakarta \\ Email: ${ }^{1}$ r.ilmalyaqin@ @oliteknikkpdumai.ac.id
}

\begin{abstract}
Abstrak
Jumlah sampah plastik setiap tahunnya akan meningkat $10 \%$ setiap tahunnya yang menjadikan masalah sebuah negara. Oleh karena itu adanya pengolahan yang tepat terhadap sampah plastik perlu dilakukan. Sebelum diolah ke pengolahan sampah plastik perlu adanya proses pencacahan menggunakan mesin pencacah plastik. Mesin pencacah plastik memiliki komponen penting yaitu pisau pencacah. Sebelum melakukan proses manufaktur pisau perlu adanya validasi pada desain bentuk pisau yang digunakan dengan pembebanan nya. Simulasi model menggunakan software merupakan salah satu cara cepat validasi model tersebut. Penelitian ini bertujuan untuk mengetahui pengaruh variasi pembebanan terhadap tegangan, regangan, deformasi dan faktor keamanan dari model. Penggunaan software ANSYS R17.2 digunakan untuk analisa model pisau mesin pencacah dengan variasi pembebanan kapasitas $5 \mathrm{~kg} / \mathrm{jam}, 10 \mathrm{~kg} / \mathrm{jam}, 20 \mathrm{~kg} / \mathrm{jam}$ dan $50 \mathrm{~kg} / \mathrm{jam}$. Hasilnya parameter tegangan, regangan dan deformasi memiliki kenaikan nilainya dengan seiring kenaikan variasi pembebanan. Nilai terbesar tegangan, regangan dan deformasi berada pada variasi $50 \mathrm{~kg} / \mathrm{jam}$ secara berturut-turut sebesar $233,79 \times 10^{-3} \mathrm{MPa} ; 12,114 \times 10^{-7} \mathrm{~m} / \mathrm{m}$ dan $20,282 \times 10^{-10} \mathrm{~m}$. Nilai faktor keamanan seluruh variasi pembebanan memiliki nilai 15 . Nilai faktor keamanan tersebut memiliki arti yaitu desain dari pisau pencacah plastik aman digunakan hingga pembebanan $50 \mathrm{~kg} / \mathrm{jam}$.
\end{abstract}

Kata Kunci: Pisau, Tegangan, Deformasi, Faktor Keamanan

\begin{abstract}
The amount of plastic waste each year will increase by $10 \%$ every year which is a problem for a country. Therefore, proper processing of plastic waste needs to be done. Before being processed into plastic waste processing, it is necessary to have a chopping process using a plastic chopping machine. The plastic chopping machine has an important component, namely the chopping knife. Before carrying out the knife manufacturing process, it is necessary to validate the design of the blade that is used with its loading. Model simulation using software is one way to quickly validate the model. This study aims to determine the effect of loading variations on stress, strain, deformation and safety factors of the model. The use of ANSYS R17.2 software is used to analyze the chopping machine knife model with a variation of $5 \mathrm{~kg} /$ hour, $10 \mathrm{~kg} / \mathrm{hour}, 20 \mathrm{~kg} / \mathrm{hour}$ and $50 \mathrm{~kg} / \mathrm{hour}$ capacities. The result is that the stress, strain and deformation parameters have an increase in value with increasing loading variations. The greatest values of stress, strain and deformation are in the variation of $50 \mathrm{~kg} /$ hour respectively $233,79 \times 10^{-3} \mathrm{MPa} ; 12,114 \times 10^{-7} \mathrm{~m} / \mathrm{m}$ dan $20,282 \times 10^{-10} \mathrm{~m}$. The value of the safety factor for all variations of loading has a value of 15 . The value of the safety factor means that the design of the plastic chopping knife is safe to use up to a loading of $50 \mathrm{~kg} / \mathrm{hour}$.
\end{abstract}


Keywords: Blade, Stress, Deformation, Safety Factor.

\section{PENDAHULUAN}

Limbah plastik atau sampah plastik merupakan masalah beberapa wilayah yang ada di negara berkembang. Jumlah sampah plastik di indonesia semakin lama akan semakin bertambah dengan jumlah 825ton pada tahun 2006 meningkat menjadi 1038 ,5ton pada tahun 2008. Jumlah tersebut akan meningkat setiap tahunnya dengan kisaran peningkatan $10 \%$ per tahunnya (Yetri, Sawir and Hidayati, 2016). Selain sampah plastik yang berada di darat, sampah plastik juga banyak ditemukan di lingkungan perairan atau laut di Indonesia. Data jumlah sampah plastik diperkuat dengan adanya data penggunaan kantong plastik di indonesia sebanyak 700 kantong/orang/tahun dengan rata-rata $0,12 \mathrm{~kg}$ sampah plastik setiap harinya (Fatimura, 2020). Sampah plastik dapat bertahan hingga bertahuntahun dapat menyebabkan pencemaran lingkungan. Selain dapat mencemarkan lingkungan, sampah plastik jika proses pengolahannya dengan dibakar maka dapat mencemari udara sehingga membahayakan manusia (Karuniastuti, 2013). Sampah plastik yang terbawa laut juga dapat mencemari biota laut yang dapat membuat bioata laut mati. Oleh karena itu, masalah sampah plastik memerlukan perhatian khusus untuk diproses lebih lanjut guna mengurangi pencemaran lingkungan sekitar (Widjanarko, 2015). Pemanfaaatan teknologi dalam memproses dapat mengurangi sampah plastik sudah sering di lakukan oleh beberapa pihak baik pemerintah maupun secara umum. Salah satu pemanfaatan plastik tersebut yaitu reaktor pirolisis untuk mengkonversikan sampah plastik menjadi bahan bakar yang bermanfaat bagi manusia (Fatimura, 2020). Proses pendaurulang sampah plastik pada dasarnya memerlukan beberapa proses lagi sebelum benar-benar untuk dilakukan proses pirolisis maupun bahan campuran beton. Bentuk pengolahan sampah plastik dapat dimulai dengan melakukan dengan mencacah plastik tersebut menggunakan mesin. Pengunaan mesin pencacah plastik dapat menghemat waktu proses pendaurulangan sampah plastik (Anggraeni and Latief, 2018).

Mesin pencacah plastik merupakan suatu mesin yang digunakan untuk memotong ukuran plastik menjadi lebih kecil. Mesin pencacah plastik memiliki beberapa komponen penyusun mesin pencacah plastik antara lain rangka mesin, pisau pencacah, saringan cacahan plastik, penutup atas dan motor penggerak (Syamsiro, Hadiyanto and Mufrodi, 2016). Beberapa penelitian yang sudah dilakukan memiliki perbedaan jenis mekanisme proses pemotongan plastik. Jenis mekanisme pencacah plastik antara lain tipe penghancur (Reddy and Raju, 2018) dan tipe gunting (Anggraeni and Latief, 2018). Mekanisme tipe penghancur memiliki bentuk pisau hook dengan beberapa mata dan bentuk pisau $\mathrm{S}$ dengan dua mata pisau (Yepes, Pelegrina and Pertuz, 2018). Sedangkan jumlah pisau yang dibutuhkan untuk mekanisme penghancur harus sesuai dengan lebar hopper penampung plastik jadi membutuhkan mata pisau yang banyak. Jenis mekanisme pencacah plastik tipe gunting memiliki model persegi panjang dengan mata pisau yang tajam sesuai Gambar 1(Pranoto et al., 2020). Pisau mekanisme tipe gunting terhubung dengan poros penggerak sehingga dapat menimbulkan gaya potong akibat putaran mesin (Orhorhoro, Ikpeand and Tamuno, 2016). Jumlah dari mata pisau yang digunakan dalam mekanisme tipe gunting minimal memiliki lima pisau. Hal tersebut menyebabkan mekanisme pencacah plastik dengan tipe gunting memiliki jumlah pisau yang relatif lebih sedikit dibandingkan dengan mesin pencacah plastik tipe penghancur. Oleh sebab itu, pisau pencacah tersebut dalam mencacah plastik memiliki nilai ekonomis dan keefektifan yang lebih baik dari pada yang lain. Mekanisme tipe gunting membantu dan mempermudah proses pencacahan plastik (Anggraeni and Latief, 2018).
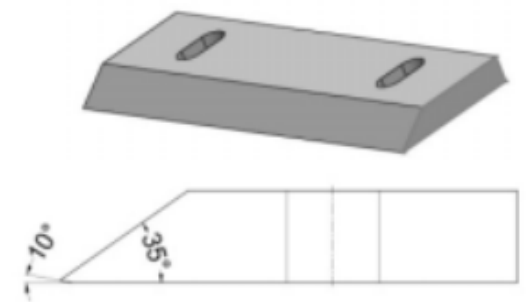

Gambar 1. Bentuk mata pisau pencacah plastik tipe gunting (Anggraeni and Latief, 2017)

Komponen pisau pencacah merupakan komponen yang penting dalam proses pencacahan plastik karena menentukan proses pencacahan plastik. Beberapa jenis bahan yang sering digunkan mesin pencacah pisau yaitu AISI 1045 (Yepes, Pelegrina and Pertuz, 2018), JIS SKD 11 (Anggraeni and Latief, 2018), HSS, ST37 dan DIN 8885 (Widjanarko, 2015). Jenis HSS merupakan jenis pisau yang banyak dipasaran untuk mata pisau mesin ketam. Tahapan awal dalam merancang suatu 
komponen mesin yaitu mendesain dan menganlisa desain yang dihasilkan. Proses analisa desain pisau mesin pencacah plastik adalah proses untuk menhasilkan produk yang maksimal dalam proses manufaktur (Pranoto et al., 2020). Kegagalan struktur komponen mesin sering terjadi pada suatu mesin dikarenakan belum adanya perhitungan dan analisa strukurtur material yang digunakan mesin tersebut. Suatu perancangan yang dilakukan harus memperhatikan kekuatan maksimum dari suatu struktur bahan yang digunakan pada komponen tersebut (Mulyadi and Hermawan, 2015). Salah satu metode untuk menganalisa secara simulasi pada suatu struktur bahan pada komponen mesin yaitu finite element.

FEA atau Finite Element Analisys adalah suatu metode untuk memperoleh pendekatan numerik sehingga dapat diselesaikan dengan komputer dengan cara mendiskretisasi atau membagi struktur komponen menjadi bagian-bagian kecil yang jumlahnya berhingga. Elemen kecil tersebut di gabungkan untuk dianalisa secara perhitungan (Rusdiyana et al., 2016). Beberapa penelitian penggunaan Finite Element Analisys tentang pisau mesin penghancur plastik sudah banyak dilakukan. Analisis dari pisau mesin penghancur PET dengan variasi bahan dan bentuk dengan menggunakan metode Finite Element Analisys memiliki hasil berupa rekomendasi pisau yang digunakan yang baik adalah AISI 1045 dengan bentuk pisau hookshaped (Yepes, Pelegrina and Pertuz, 2018). Penggunaan metode Finite Element Analisys dapat menganalisa tegangan pada pisau pemotong sampah plastik. Hasil dari analisa tersebut memperlihatkan sebarahan tegangan pada pisau pemotong tersebut. Tegangan yang dihasilkan masih di bawah tegangan luluh dari bahan tersebut (Nasr and Yehia, 2019). Angka keamanan dari pisau pencacah plastik juga dapat diketahui dengan menggunakan metode Finite Element Analisys (Pranoto et al., 2020).

Berdasarkan permasalahan yang dijabarkan sebelumnya, tujuan dari penelitian ini yaitu mengetahui pengaruh variasi pembebanan terhadap desain pisau mesin pencacah menggunakan Finite Element Analisys. Hasil yang diperoleh yaitu berupa meliputi tegangan, regangan dan deformasi pada pisau pencacah plastik serta safety factor pada setiap pembebanan sebagai acuan untuk proses manufaktur dari pisau mesin pencacah plastik.

\section{METODE}

Simulasi pemodelan desain pisau mesin pencacah plastik di gambar 3D menggunakan software CAD Autodesk Inventor 2019. Pemilihan desain dari mata pisau menyesuaikan dari dudukan mekanisme pemotongan pencacah plastik. Oleh karena itu, desain dari pisau memiliki bentuk dan dimensi yang di tunjukkan pada Tabel 1. Model gambar hasil dari penentuan parameter geometri dapat dibentuk sesuai Gambar 2. Bentuk yang digunakan menyesuaikan tingkat kemudahan dalam pembuatan dan modifikasi pisau pencacah. Penentuan bahan pada model pisau pencacah bahan menggunakan baja paduan HSS $18 \%$ (eq. ASTM A600) yang memiliki sifat mekanik dan fisik sesuai dengan Tabel 2. Pemilihan bahan HSS 18\% karena mata pisau tersebut sudah dijual di pasaran sebagai mata pisau mesin potong kayu serta mudah untuk di modifikasi bentuknya. Mekanisme pemotongan pisau pencacah plastik model gunting dapat disimulasikan menggunakan putaran yang memiliki bentuk pada Gambar 3. Pemodelan simulasi menggunakan software Workbench ANSYS R17.2. Parameter-parameter pemodelan simulasi di masukkan kedalam sistem software pada bagian data model simulasi.

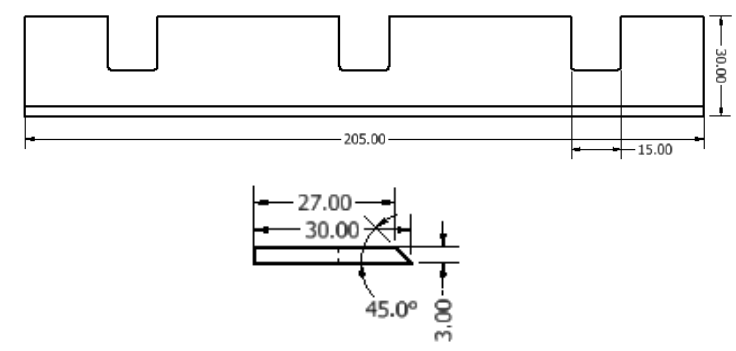

Gambar 2. Model perancangan pisau mesin pencacah plastik

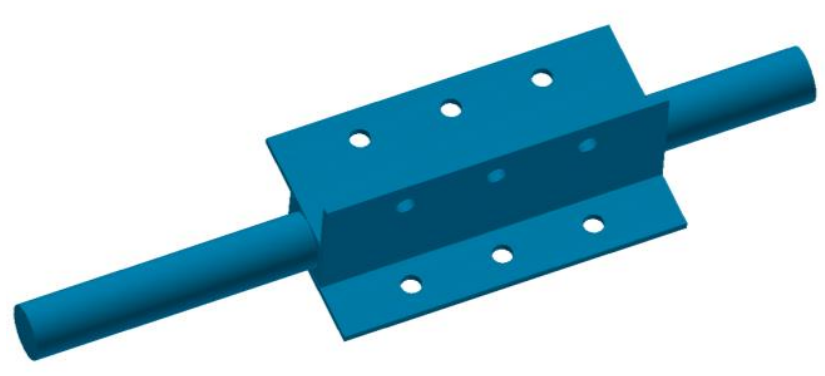

Gambar 3. Mekanisme dudukan pisau pencacah plastik

Analisis sistem pemodelan dengan Finite Element Analysis menggunakan software dipengaruhi dengan sistem meshing pada model yang dianalisisnya. Penggunaan meshing pada model pisau mesin pencacah plastik menggunakan tipe tetrahedral dengan jumlah Node sebanyak 30168 dan jumlah Element sebanyak 14858. Penentuan mesh menggunakan skala paling halus agar simulasi pemodelan lebih maksimal hasil dari perhitungannya. Pengaturan bentuk dari mesh pada 
model desain pisau pencacah plastik dapat di tunjukkan pada Gambar 4.

Tabel I. Ukuran geometri pisau pencacah plastik

\begin{tabular}{cc}
\hline Geometri & Nilai \\
\hline Panjang & $210 \mathrm{~mm}$ \\
Lebar & $30 \mathrm{~mm}$ \\
Tebal & $3 \mathrm{~mm}$ \\
Sudut Mata Pisau & $45^{\circ}$ \\
Panjang Mata Pisau & $3 \mathrm{~mm}$ \\
\hline
\end{tabular}

Tabel II Sifat mekanik bahan pisau pencacah plastik

\begin{tabular}{cc}
\hline Sifat Mekanik & Nilai \\
\hline Densitas & $8670 \mathrm{~kg} / \mathrm{m}^{3}$ \\
Posion Ratio & $0,27-0,30$ \\
Modulus Young's & $190-210 \mathrm{GPa}$ \\
Yield Strength & $154 \mathrm{MPa}$ \\
Tensile Strength & $231 \mathrm{MPa}$ \\
Shear Modulus & $77,8 \mathrm{GPA}$ \\
Sifat & Isotropik \\
\hline
\end{tabular}
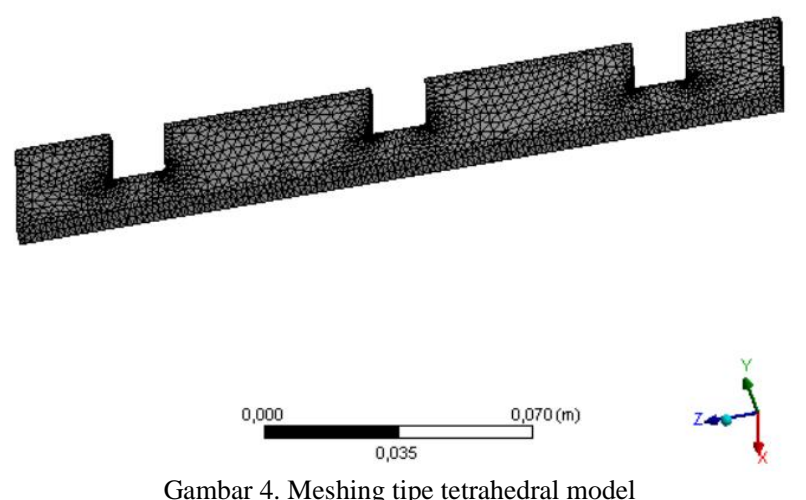

Penentuan kondisi awal yang digunakan pada model yaitu menggunakan fixed support atau tumpuan tetap yang di tunjukkan dengan Gambar 5. Penggunaan parameter fixed support berada pada bagian atas pisau yang memiliki kontak langsung dengan bagian penggerak pisau dinamis pada mesin pencacah plastik. Sedangkan untuk pembebanan menggunakan pembebanan sebesar variasi kapasitas dari pisau yaitu $5 \mathrm{~kg} / \mathrm{jam}, 10 \mathrm{~kg} / \mathrm{jam}, 20 \mathrm{~kg} / \mathrm{jam}$ dan $50 \mathrm{~kg} / \mathrm{jam}$. Kondisi kerja pisau pada proses pemotongan plastik menggunakan spesifikasi motor besin yang di tunjukkan Tabel III. Konversi dari pembebanan terhadap gaya yang diberikan pada pemodelan menggunakan persamaan berikut

$$
F=m \cdot g
$$

Keterangan

$\mathrm{F} \quad=$ Gaya pembebanan $(\mathrm{N})$

$\mathrm{m} \quad=$ Massa plastik yang terbeban $(\mathrm{kg})$

$\mathrm{g}=$ Konstanta gaya gravitasi $\left(\mathrm{m} / \mathrm{s}^{2}\right)$

Jika dikonversikan pembebanan tersebut memiliki nilai sebesar $50 \mathrm{~N} ; 100 \mathrm{~N} ; 200 \mathrm{~N}$ dan $500 \mathrm{~N}$.
Pembebanan diletakkan pad bagian bawah pisau karena yang mengalami pembebanan saat pisau bekerja. Pembebanan pada model di tunjukkan pada Gambar 6.

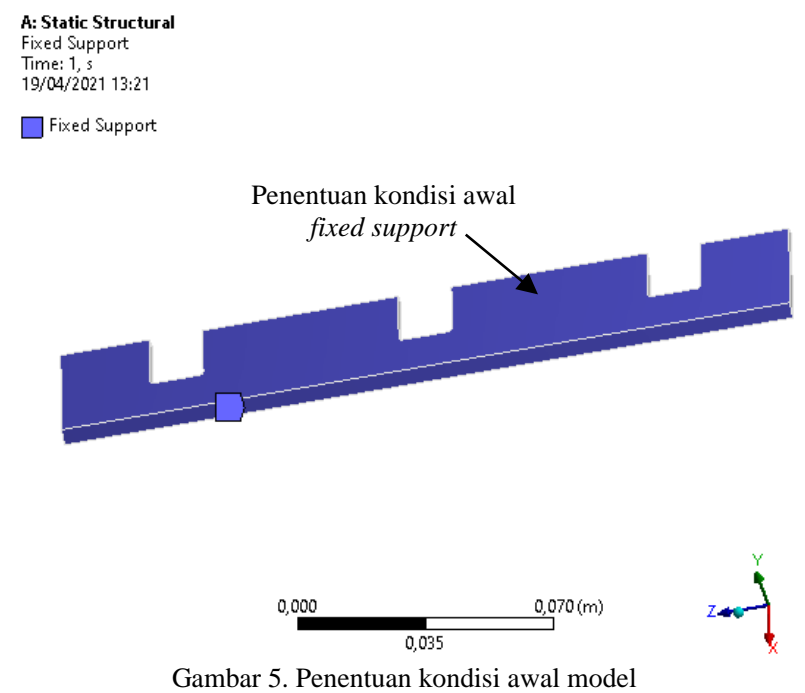

Tabel III Kondisi kerja pisau pemotong

\begin{tabular}{cc}
\hline Sepsifikasi & Nilai \\
\hline Kecepatan Putar & $650 \mathrm{RPM}$ \\
Daya & $6,5 \mathrm{HP}$ \\
\hline
\end{tabular}

A: Static Structural

Force
Time: 1 ,

Time: 1, 5
19/04/2021 13:44

$\square$ Force: $500, \mathrm{~N}$

Components: 0,;500;0, N

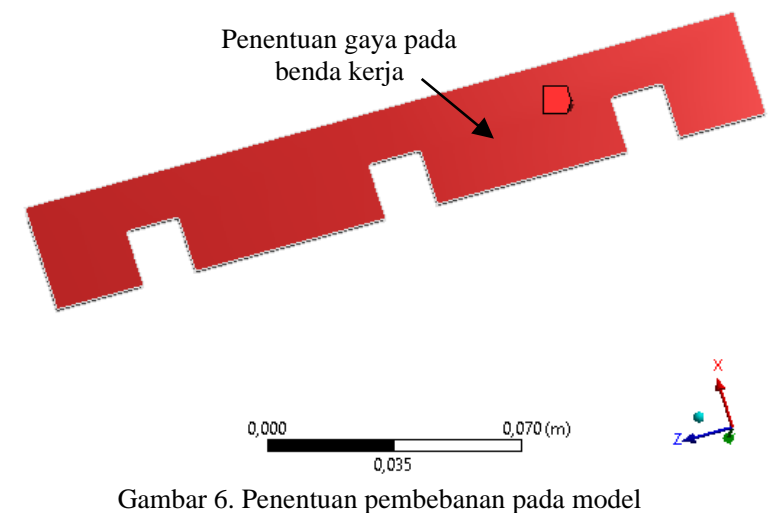

Post processing pada bagian permodalan yaitu penentuan hasil yang diperoleh pada simulasi model pisau mesin pencacah plastik. Parameter hasil proses simulasi pada model ini antara lain total deformation, equivalent elastic strain, equivalent stress dan safety factor. Penentuan nilai strain dan stress secara teoritis dapat diselesaikan dengan persamaan berikut

$\left\{\begin{array}{l}\boldsymbol{\sigma}_{x x} \\ \boldsymbol{\sigma}_{y y} \\ \boldsymbol{\sigma}_{z z}\end{array}\right\}=\frac{E}{(1+v)(1-2 v)}\left\{\begin{array}{l}(1-v) \varepsilon_{x}+v \varepsilon_{y}+v \varepsilon_{z} \\ v \varepsilon_{x}+(1-v) \varepsilon_{y}+v \varepsilon_{z} \\ v \varepsilon_{x}+v \varepsilon_{y}+(1-v) \varepsilon_{z}\end{array}\right\}$ 
$\sigma \quad=$ Tegangan yang terjadi

$\varepsilon \quad=$ Regangan

$v \quad=$ Poison ratio

$\mathrm{E} \quad=$ Modulus young

Sedangkan untuk perhitungan angka keamanan atau safety factor dapat di tunjukkan dengan persamaan berikut

$$
S F=\frac{\sigma_{\max }}{\sigma_{\max \text { bahan }}}
$$

Keterangan

$$
\begin{array}{ll}
S F & =\text { Angka Keamaan } \\
\sigma_{\max } & =\text { Tegangan yang diijinkan bahan } \\
\sigma_{\max \text { bahan }} & =\text { Tegangan yang diterima bahan }
\end{array}
$$

\section{HASIL DAN PEMBAHASAN}

\section{Equivalent Stress}

Simulasi pemodelan simulasi pada pisau mesin pencacah plastik menggunakan metode elemen hingga untuk menghitung nilai-nilai untuk menemukan solusi perkiraan untuk permasalahan nilai batas pada suatu model. Simulasi model 3D pada pisau mesin pencacah plastik menggunakan analisa tegangan statis dengan tidak adanya pengaruh getaran dan dinamika. Hasil analisa variasi pembebanan pada simulasi model 3D menunjukkan adanya bentuk yang sama terhadap persebaran tegangan pada model pisau pencacah plastik yang di tunjukkan pada Gambar 7, Gambar 8, Gambar 9, dan Gambar 10. Kontur hasil pemodelan menunjukkan sisi luar pisau dan sisi mata pisau yang memiliki nilai tegangan tertingginya (Pranoto et al., 2020). Hal tersebut dikarenakan daerah mata pisau merupakan daerah yang memiliki ketebalan lebih tipis dari daerah lainnya sehingga tegangan menginisiasikan dari daerah yang paling tipis (Kumaran et al., 2020).

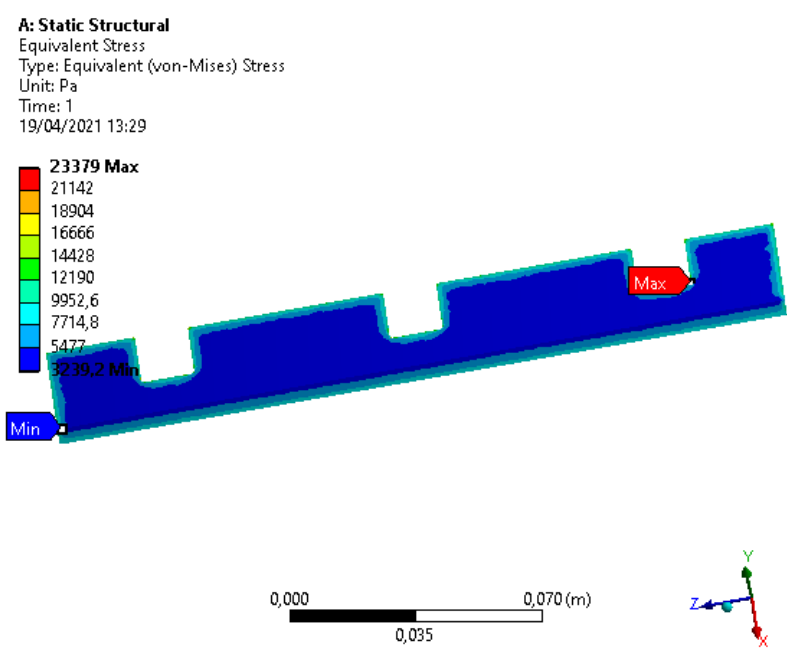

Gambar 7. Hasil Simulasi tegangan pada variasi beban $5 \mathrm{~kg} / \mathrm{jam}$

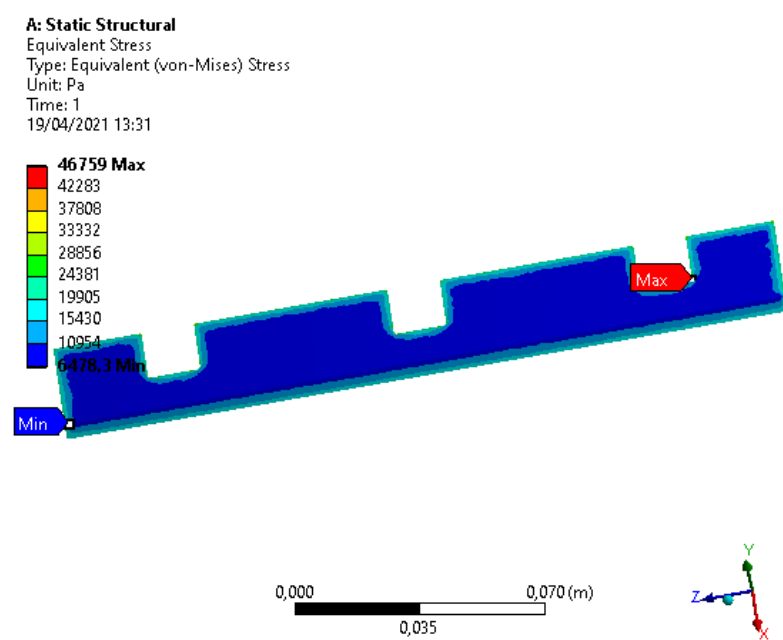

Gambar 8. Hasil Simulasi tegangan pada variasi beban $10 \mathrm{~kg} / \mathrm{jam}$

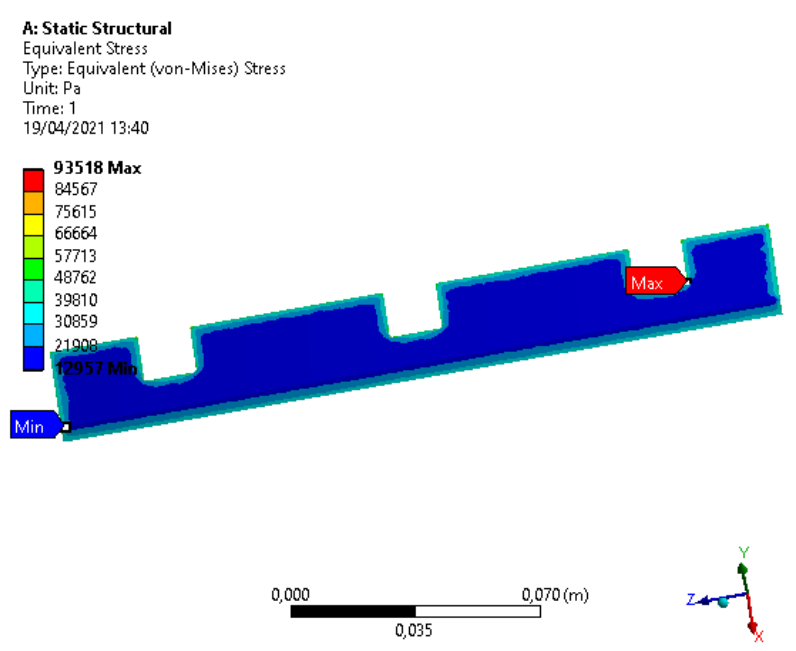

Gambar 9. Hasil Simulasi tegangan pada variasi beban 20 kg/jam

A: Static Structural

Equivalent Stress

Type: Equivalent (von-Mises) Stress

Unit: $\mathrm{Pa}$

19/04/2021 13:42
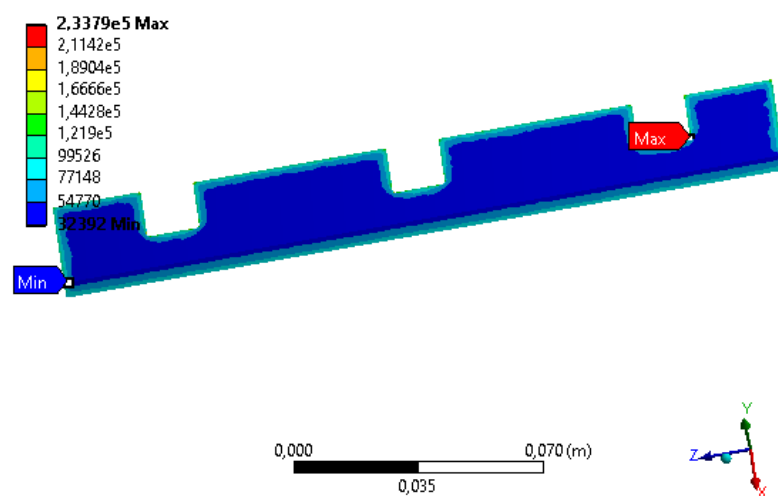

Gambar 10. Hasil Simulasi tegangan pada variasi beban $50 \mathrm{~kg} / \mathrm{jam}$

Gambar 11 menunjukkan adanya kenaikan nilai tegangan dengan bertambahnya kapasitas mesin pada pisau pencacah plastik. Hasil dari pemodelan didapatkan nilai tegangan maksimum pada variasi pembebanan $5 \mathrm{~kg} / \mathrm{jam}, 10 \mathrm{~kg} / \mathrm{jam}, 20$ $\mathrm{kg} / \mathrm{jam}$ dan $50 \mathrm{~kg} / \mathrm{jam}$ secara berturut-turut yaitu $23,379 \times 10^{-3} \mathrm{MPa} ; 46,759 \times 10^{-3} \mathrm{MPa} ; 95,518 \times 10^{-}$ 
${ }^{3} \mathrm{MPa}$ dan $233,79 \times 10^{-3} \mathrm{MPa}$, sedangkan untuk tegangan minimum yaitu $3,239 \times 10^{-3} \mathrm{MPa} ; 6,478 \times$ $10^{-3} \mathrm{MPa} ; 12,957 \times 10^{-3} \mathrm{MPa}$ dan $32,392 \times 10^{-3} \mathrm{MPa}$. Hasil pemodelan dengan variasi pembebanan pada pisau pencacah plastik tersebut didapatkan nilai tegangan yang selalu meningkat seiring dengan naiknya kapasitas yang digunakan pada mesin pencacah plastik. Hal tersebut dikarenakan penentuan tegangan memiliki perbandingan yang lurus dengan besaran gaya yang diterima suatu benda (Sitepu and Hamzah, 2016). Hal ini juga memperlihatkan nilai Tegangan terbesar pada pembebanan $50 \mathrm{~kg} / \mathrm{jam}$ yaitu dengan nilai $233,79 \mathrm{x}$ $10^{-3} \mathrm{MPa}$. Nilai tegangan tersebut masih aman dibawah nilai batas tegangan yang diijinkan pada bahan yang digunakan pada pembuatan mesin pencacah plastik tersebut (Djumhariyanto, 2016).

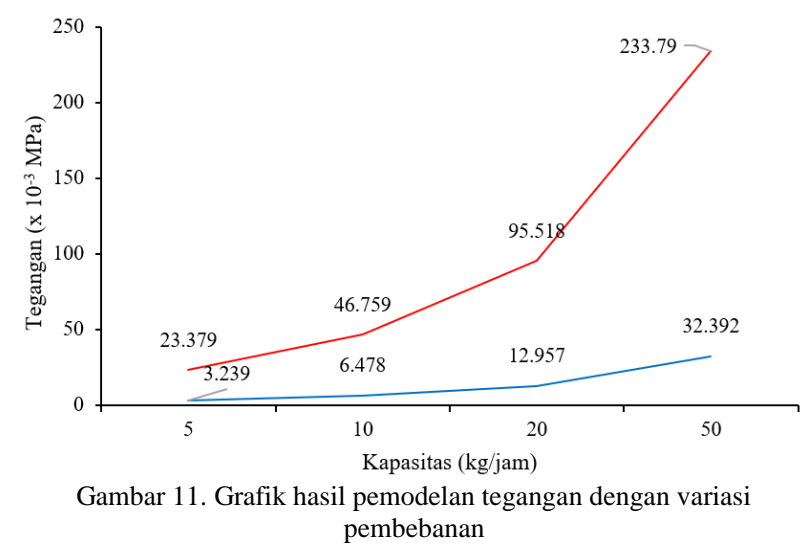

\section{Equivalent Elastic Strain}

Regangan merupakan salah satu aspek luaran pada model simulasi yang dipengaruhi jenis bahan. Gambar 12, Gambar 13, Gambar 14 dan Gambar 15 menunjukkan hasil dari simulasi model pada pisau pencacah plastik yang telah dilakukan. Variasi pembebanan pada simulasi model tidak mempengaruhi bentuk kontur regangan yang dihasilkan. Nilai regangan terbesar berada di bagian tepi yang dapat menginisiasikan regangan ke seluruh model. Bentuk kontur regangan memiliki kemiripan dengan bentuk kontur tegangan hasil simulasi pemodelan. Hal tersebut dikarenakan distribusi tegangan dan regangan dipengaruhi oleh kondisi pembebanan yang diterapkan pada model simulasi (Ramadhan, Mangalla and Samhuddin, 2018). Kesamaan tersebut dapat dibuktikan dengan teoritis dengan persamaan dasar dari hukum hooke pada suatu bahan sebagai berikut (Erokhin, Kalachnikov and Kalashnikov, 2018)

$$
\sigma=E \frac{\Delta x}{x}
$$

Dimana $\sigma$ merupakan tegangan, $\mathrm{E}$ merupakan modulus young's, dan $\frac{\Delta x}{x}$ merupakan regangan atau sering diberikan simbol $\varepsilon$. Persamaan tersebut memperlihatkan adanya keterkaitan $\sigma$ dengan $\varepsilon$ yang memiliki perbandingan yang berkesinambungan.
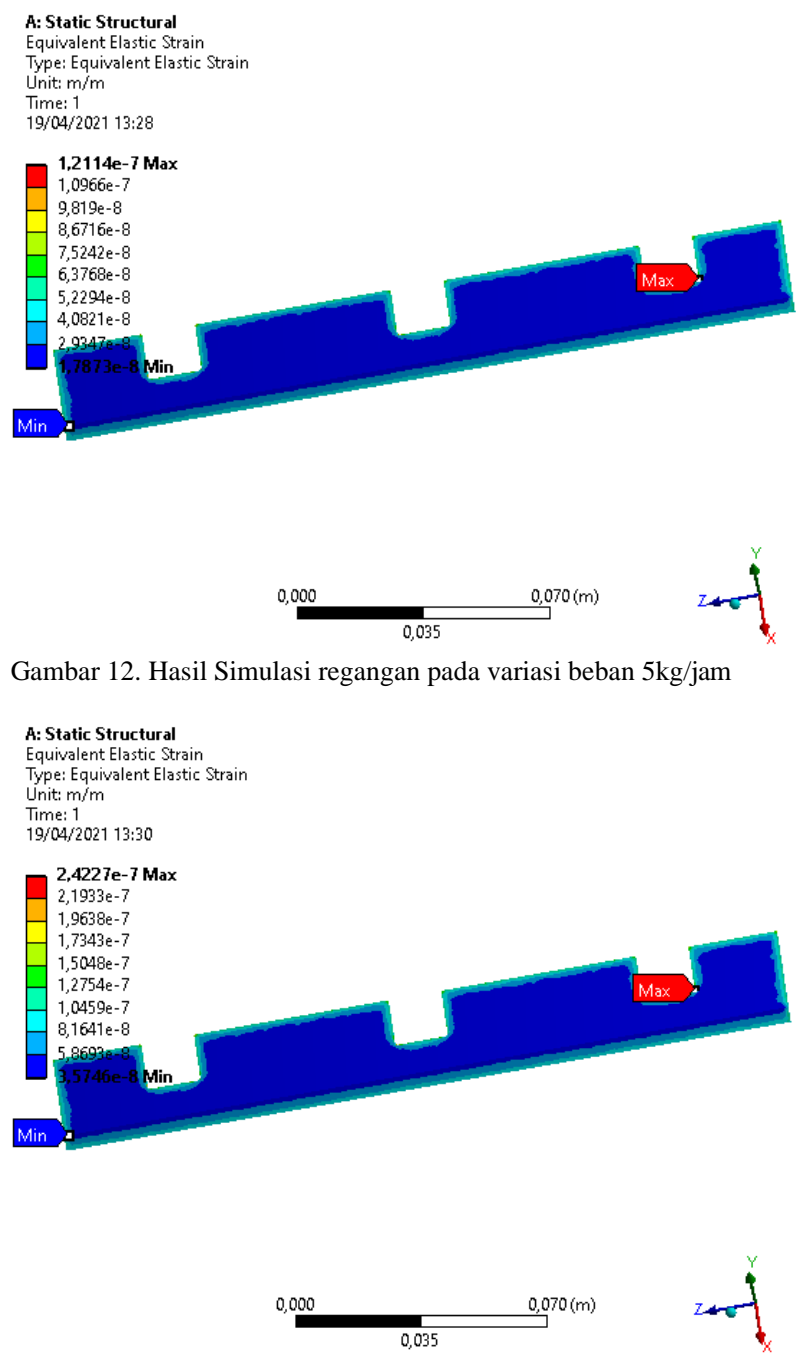

Gambar 13. Hasil Simulasi regangan pada variasi beban 10kg/jam

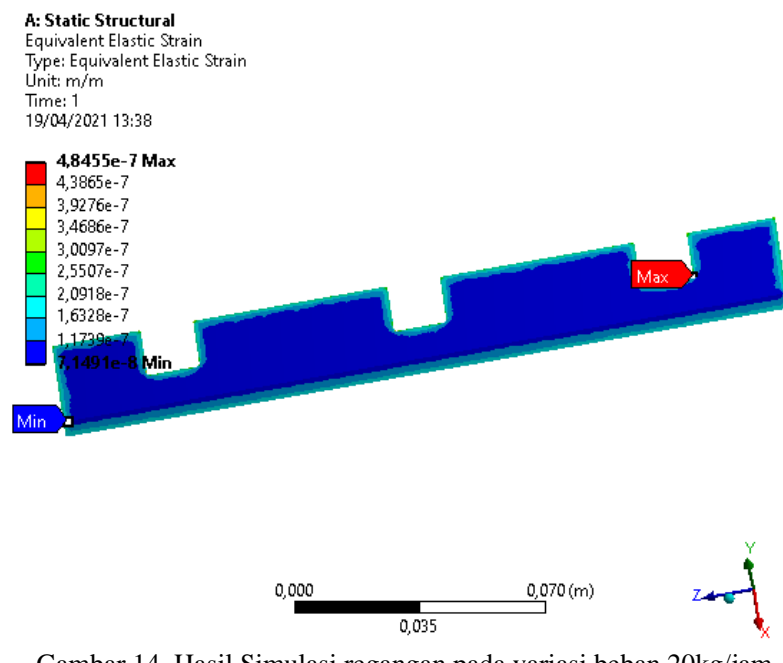

Gambar 14. Hasil Simulasi regangan pada variasi beban $20 \mathrm{~kg} / \mathrm{jam}$ 
A: Static Structural

Equivalent Elastic Strain

Type: Equivalent Elastic Strain

Unit: $m / m$

19/04/2021 13:41
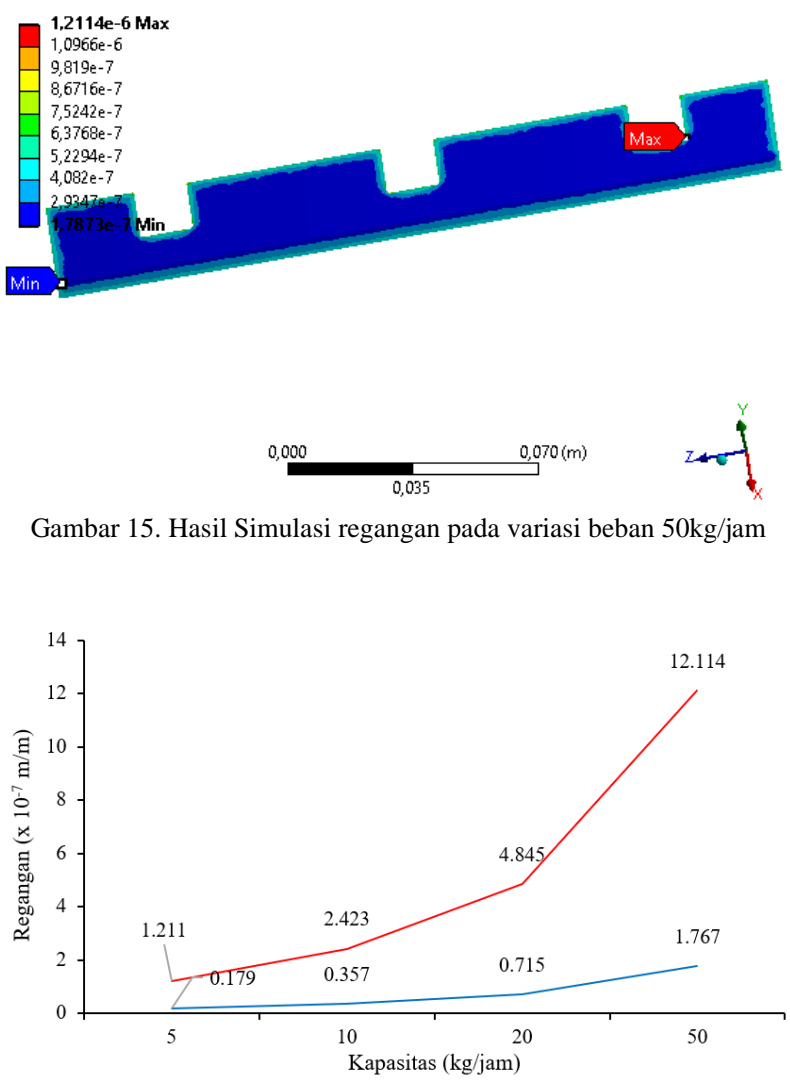

Gambar 16. Grafik hasil pemodelan regangan dengan variasi pembebanan

Gambar 16 menunjukkan hasil simulasi model pisau pencacah plastik antara regangan dengan variasi beban. Nilai regangan akan naik seiring dengan naiknya pembebanan pada pisau pencacah plastik. Hasil dari pemodelan didapatkan nilai regangan maksimum dengan variasi pembebanan $5 \mathrm{~kg} / \mathrm{jam}, 10 \mathrm{~kg} / \mathrm{jam}, 20 \mathrm{~kg} / \mathrm{jam}$ dan $50 \mathrm{~kg} / \mathrm{jam}$ berturut-turut adalah $1,211 \times 10^{-7} \mathrm{~m} / \mathrm{m} ; 2,423 \times 10^{-}$ ${ }^{7} \mathrm{~m} / \mathrm{m} ; 4,845 \times 10^{-7} \mathrm{~m} / \mathrm{m}$ dan $12,114 \times 10^{-7} \mathrm{~m} / \mathrm{m}$, sedangkan untuk regangan minimum yaitu $0,179 \mathrm{x}$ $10^{-7} \mathrm{~m} / \mathrm{m} ; 0,357 \times 10^{-7} \mathrm{~m} / \mathrm{m} ; 0,715 \times 10^{-7} \mathrm{~m} / \mathrm{m}$ dan $1,767 \times 10^{-7} \mathrm{~m} / \mathrm{m}$. Nilai regangan terbesar pada simulasi pemodelan yaitu $12,114 \times 10^{-7} \mathrm{~m} / \mathrm{m}$ pada variasi kapasitas $50 \mathrm{~kg} / \mathrm{jam}$.

\section{Total Deformation}

Deformasi merupakan salah satu luaran dari simulasi model pada pisau pencacah plastik yang diperlukan untuk menentukan model yang digunakan cukup tangguh untuk menahan beban sesuai yang diberikan (Wibawa, 2019). Hasil dari simulasi pemodelan terlihat persebaran deformasi berada di bagian tepi model. Gambar 17, Gambar 18, Gambar 19 dan Gambar 19 menunjukkan kontur dari distribusi deformasi pada model pisau pencacah plastik hasil simulasi. Bentuk tersebut menunjukkan ketidak signifikan dari deformasi pada model pisau pencacah plastik sehingga terlihat bahwa pisau tidak akan berubah bentuk geometri setelah menerima beban. Hal tersebut dikarenakan tegangan yang diberikan masih berada di daerah elastis bahan yang digunakan (Yin and $\mathrm{Xu}, 2018$ ). Deformasi menjadi aspek penting dalam analisa ini dikarenakan dapat merubah bentuk komponen sehingga dapat menjadikan pisau menurun secara fungsi kegunaannya (Pranoto et al., 2020).

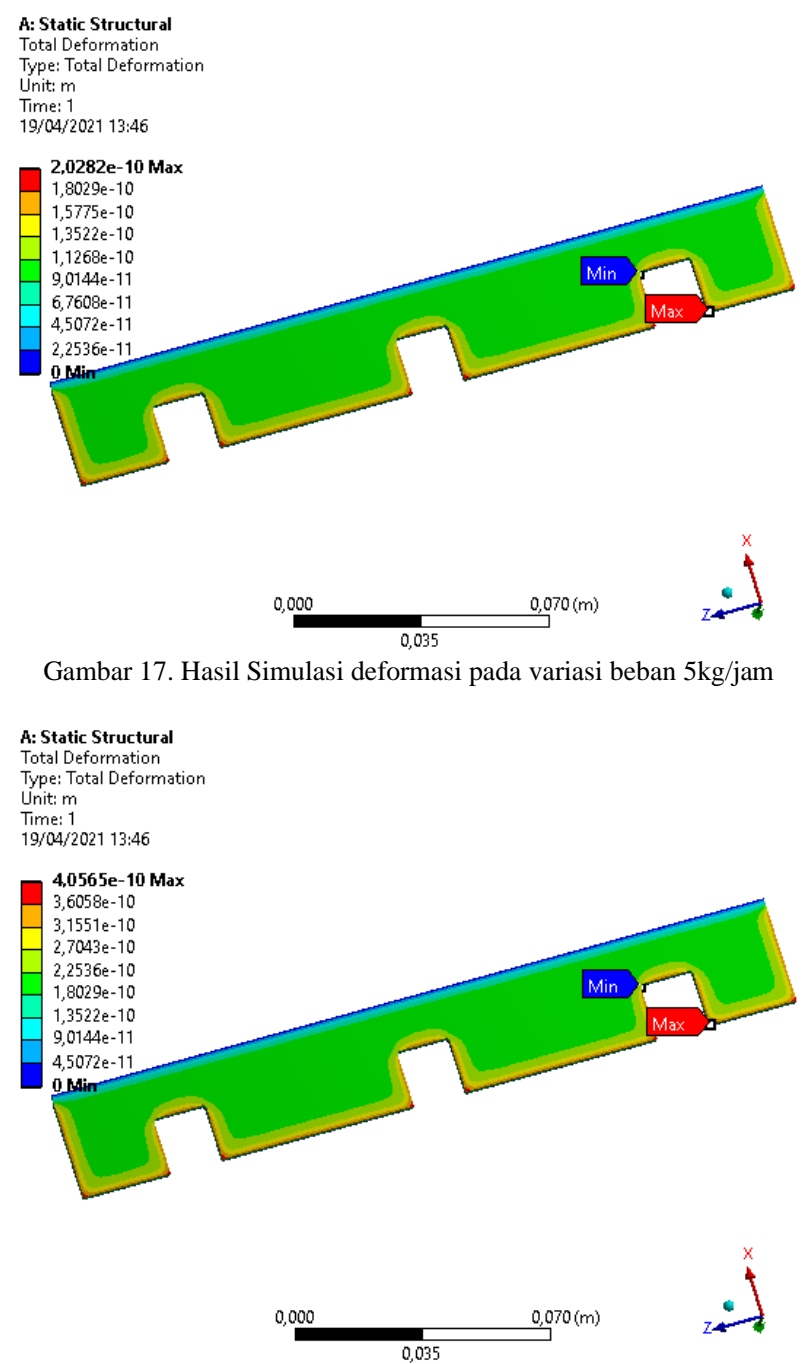

Gambar 18. Hasil Simulasi deformasi pada variasi beban $10 \mathrm{~kg} / \mathrm{jam}$ 

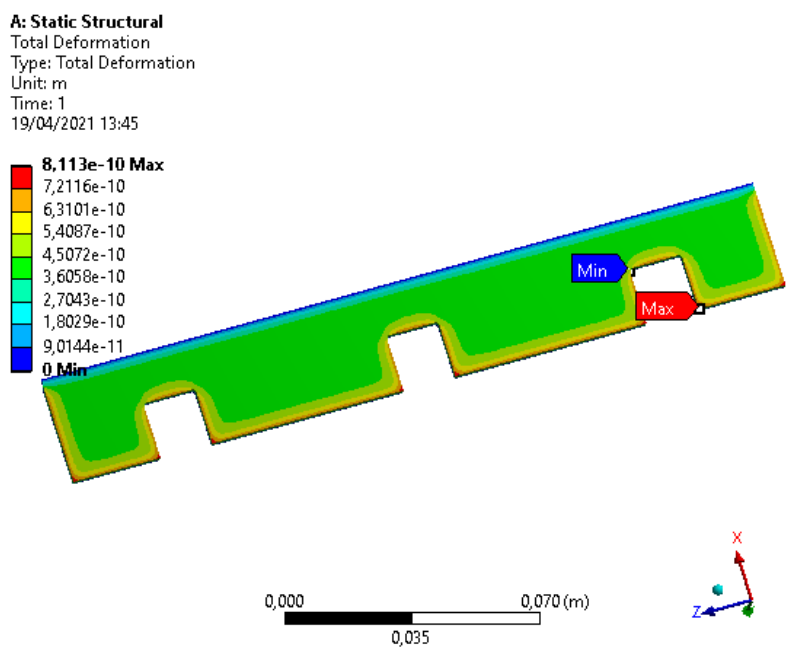

Gambar 19. Hasil Simulasi deformasi pada variasi beban 20kg/jam

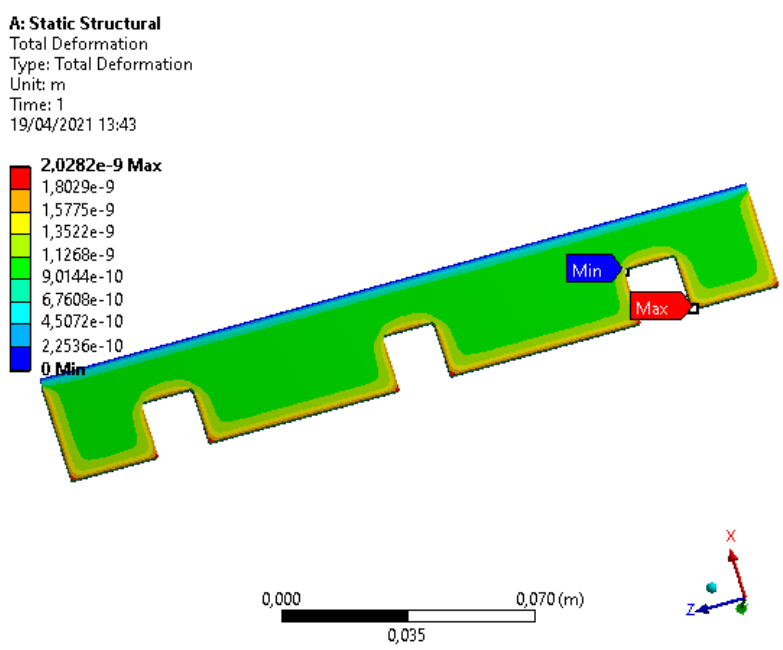

Gambar 20. Hasil Simulasi deformasi pada variasi beban $50 \mathrm{~kg} / \mathrm{jam}$

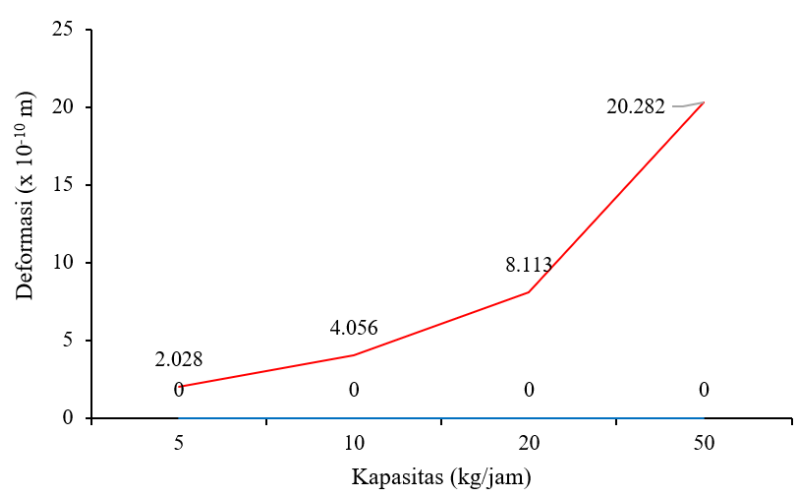

Gambar 21. Grafik hasil pemodelan deformasi dengan variasi pembebanan untuk deformasi minimum seluruh variasi yaitu $0 \mathrm{~m}$ atau tidak terjadi perubahan apapun. Nilai regangan terbesar pada simulasi pemodelan yaitu 20,282 x 10${ }^{10} \mathrm{~m}$ pada variasi kapasitas $50 \mathrm{~kg} / \mathrm{jam}$. Hasil simulasi pemodelan ketika pisau pencacah plastik diberi beban yang paling tinggi, pisau tidak berubah secara signifikan deformasinya. Hal tersebut menunjukkan bahwa komponen tidak akan rusak dan dapat diterapkan pada kegunaannya (Pratama and Mahardika, 2018).

\section{Safety Factor}

Faktor keamanan atau safety factor merupakan salah satu aspek yang digunakan untuk mengevaluasi agar sebuah perancangan terjamin keamanan dari dimensi yang maksimal. Faktor keamanan dapat ditentukan dengan perbandingan antara tegangan yang diberikan pada desain dengan tegangan luluh pada bahan (Wibawa, 2019). Hasil dari simulasi model ditunjukkan pada Gambar 22, Gambar 23, Gambar 24 dan Gambar 25 yang memiliki nilai minium dan maksimum 15. Distribusi hasil simulasi pemodelan menunjukkan bahwa distribusi merata angka keamanan pada seluar daerah atau bagian yang ada pada model pisau mesin pencacah plastik. Hasil angka keamanan tersebut menunjukkan keamanan pada model perancangan pisau mesin pencacah plastik aman dari pembebanan yang diberikan. Keamanan suatu komponen dapat ditunjukkan dengan nilai safety factor yang didapatkan $>1$ dari tegangan yang bekerja (Pranoto et al., 2020). Secara umum nilai faktor keamanan dari penelitian ini sudah memenuhi syarat untuk mampu menahan beban.

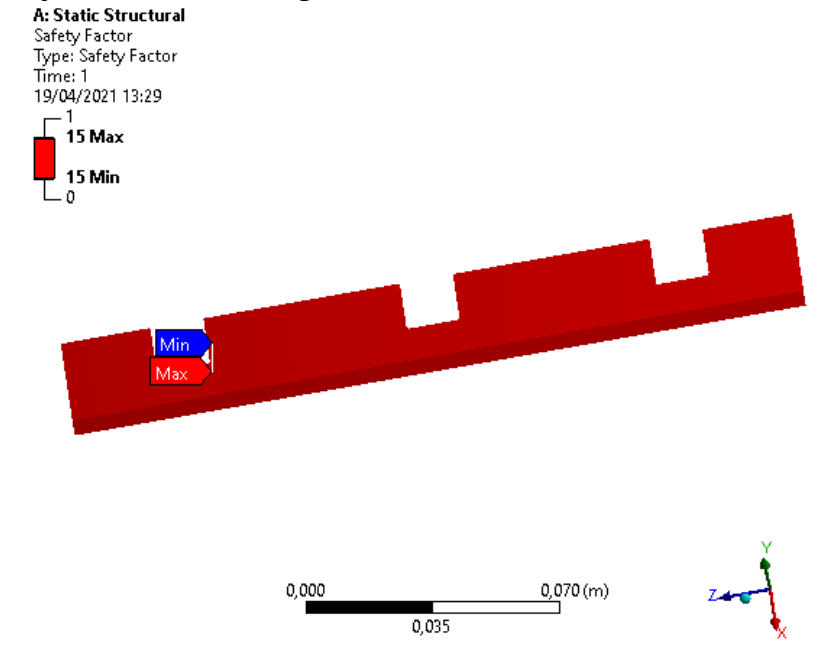

Gambar 21 menunjukkan grafik deformasi dengan variasi pembebanan hasil pemodelan simulasi. Nilai deformasi akan naik seiring dengan kenaikan kapasitas yang diterima dari pisau pencacah plastik. Hasil dari pemodelan didapatkan nilai deformasi dengan variasi pembebanan $5 \mathrm{~kg} / \mathrm{jam}, 10 \mathrm{~kg} / \mathrm{jam}, 20 \mathrm{~kg} / \mathrm{jam}$ dan $50 \mathrm{~kg} / \mathrm{jam}$ berturut-turut adalah $2,028 \times 10^{-10} \mathrm{~m} ; 4,056 \times 10^{-10} \mathrm{~m}$; $8,113 \times 10^{-10} \mathrm{~m}$ dan $20,282 \times 10^{-10} \mathrm{~m}$, sedangkan

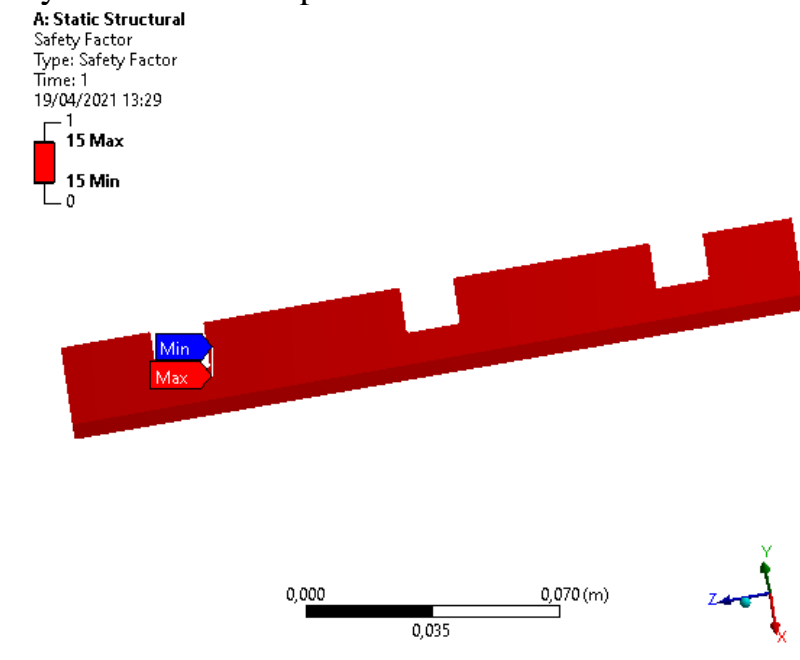

Gambar 22. Hasil Simulasi angka keamanan pada variasi beban $5 \mathrm{~kg} / \mathrm{jam}$ 


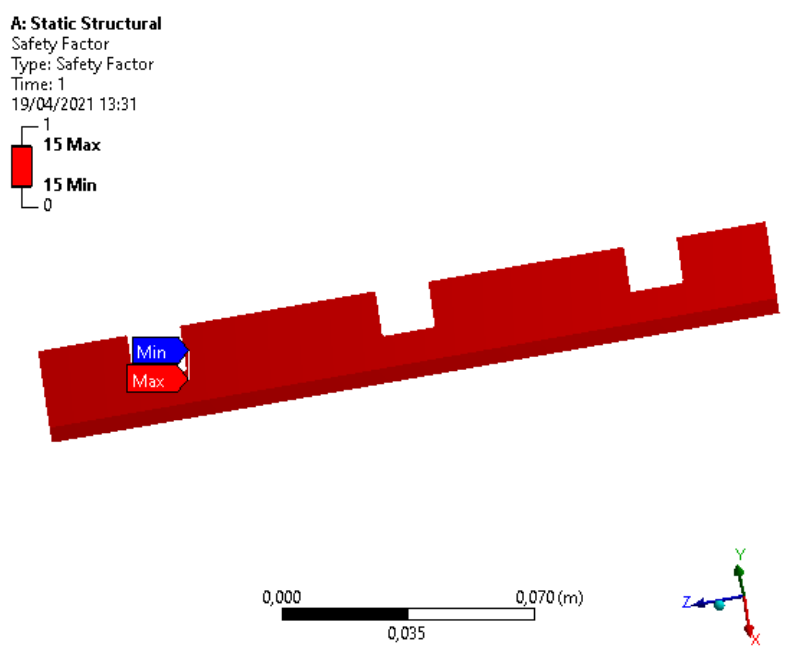

Gambar 23. Hasil Simulasi angka keamanan pada variasi beban $10 \mathrm{~kg} / \mathrm{jam}$
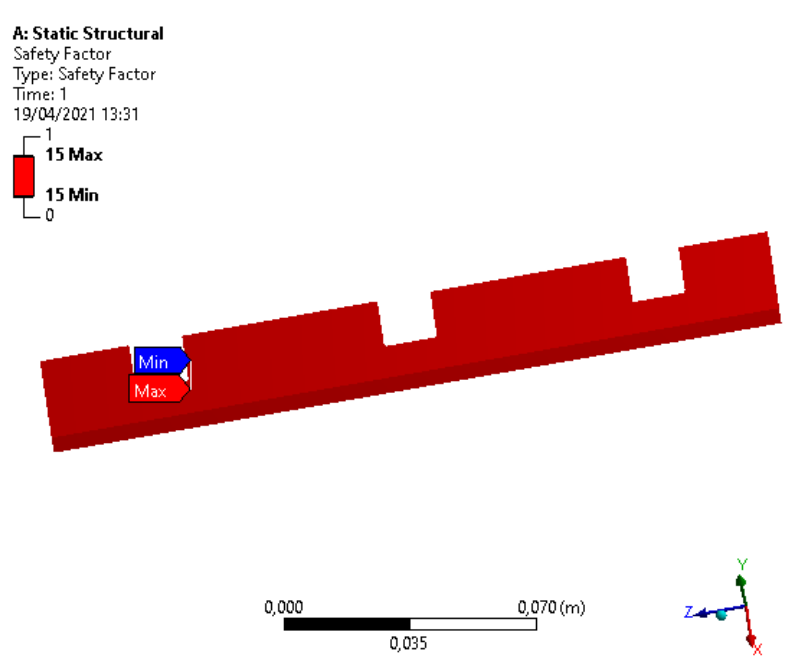

Gambar 24. Hasil Simulasi angka keamanan pada variasi beban $20 \mathrm{~kg} / \mathrm{jam}$
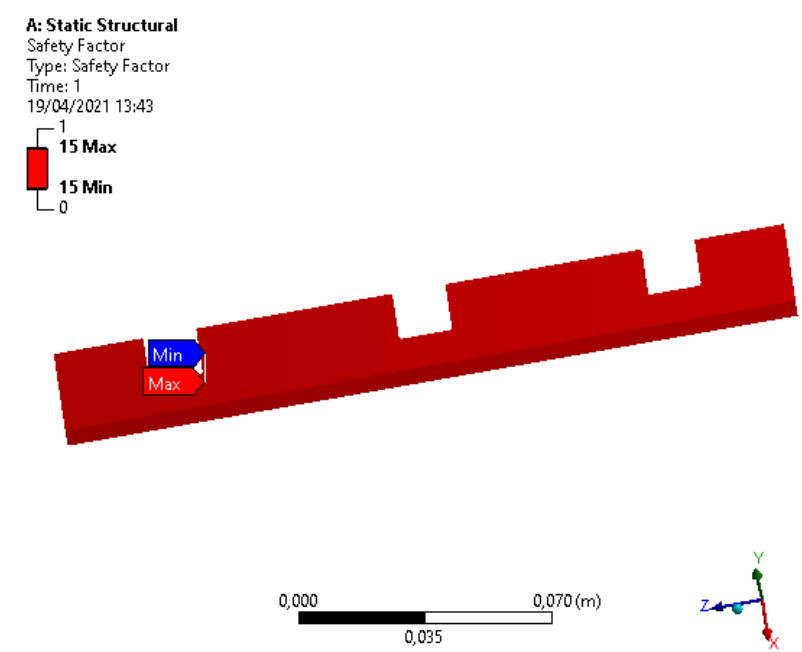

Gambar 25. Hasil Simulasi angka keamanan pada variasi beban $50 \mathrm{~kg} / \mathrm{jam}$

\section{PENUTUP}

\section{Kesimpulan}

Berdasarkan pemaparan analisa dan pembahasan dapat disimpulkan bahwa distribusi tegangan, regangan dan deformasi pada pemodelan pisau mesin pencacah plastik dengan variasi pembebanan pada $5 \mathrm{~kg} / \mathrm{jam}, 10 \mathrm{~kg} / \mathrm{jam}, 20 \mathrm{~kg} / \mathrm{jam}$ dan $50 \mathrm{~kg} / \mathrm{jam}$ mengalami peningkatan disetiap pembebanan yang diberikan. Nilai tegangan, regangan dan deformasi terbesar berada pada pembebanan $50 \mathrm{~kg} / \mathrm{jam}$ sebesar $233,79 \times 10^{-3} \mathrm{MPa} ; 12,114 \times 10^{-7} \mathrm{~m} / \mathrm{m}$ dan $20,282 \times$ $10^{-10} \mathrm{~m}$. Nilai faktor keamanan setiap variasi pembebanan memiliki nilai 15. Hal tersebut menunjukkan bahwa model perancangan dari pisau mesin pencacah plastik aman digunakan karena nilai faktor keamanannya $>1$ dari tegangan yang bekerja pada benda kerja. Model yang sudah dirancang dan bahan HSS $18 \%$ dapat direkomendasikan sebagai pisau mesin pencacah plastik.

\section{Saran}

Saran yang diberikan yaitu adanya penelitian selanjutnya dengan desain dan pemilihan badan yang lain agar mengetahui perbandingan dari penggunaan bahan yang digunakan. Selain itu penelitian tentang fatigue life bahan sangat diperlukan untuk mengetahui umur pakai pada perancangan model yang digunakan.

\section{DAFTAR PUSTAKA}

Anggraeni, N. D. and Latief, A. E. (2017) 'Modifikasi Mata Pisau Mesin Pencacah Plastik Tipe Polyethylene', in Seminar Nasional Rekayasa dan Aplikasi Teknik Mesin di Industri - XVI, pp. 69-78.

Anggraeni, N. D. and Latief, A. E. (2018) 'Rancang Bangun Mesin Pencacah Plastik Tipe Gunting', Jurnal Rekayasa Hijau, 2(2), pp. 185-190.

Djumhariyanto, D. (2016) 'Analisa Tegangan Poros Roda Mobil Listrik Dengan Metode Elemen Hingga', J-Proteksion, 1(1), pp. 8-14.

Erokhin, K. M., Kalachnikov, E. S. and Kalashnikov, N. P. (2018) 'Relation between the Young's Modulus in Hooke's Law and the Binding Energy of a Single Atom in Solid', International Journal of Advanced Research in Physical Science (IJARPS), 5(12), pp. 3840.

Fatimura, M. (2020) 'Evaluasi Kinerja Reaktor Pirolisis Non Katalis Dalam Mengkonversikan Limbah Plastik Menjadi Bahan Bakar Minyak', Jurnal Ilmiah Teknik Kimia, 4(1), pp. 1-7.

Karuniastuti, N. (2013) 'Bahaya Plastik terhadap 
Kesehatan dan Lingkungan', Swara Patra: Majalah Pusdiklat Migas, 3(1), pp. 6-14.

Kumaran, P. et al. (2020) 'Design and analysis of shredder machine for e - Waste recycling using CATIA', IOP Conference Series: Materials Science and Engineering, 993(1), pp. 0-7.

Mulyadi, S. and Hermawan, Y. (2015) 'Analisa Kegagalan Produk Cutting Disc Mesin Pemotong Krupuk Singkong Dengan Metode Elemen Hingga', Rotor, 8(2), pp. 1-9.

Nasr, M. F. and Yehia, K. A. (2019) 'Stress Analysis of a Shredder Blade for Cutting Waste Plastics', Journal of International Society for Science and Engineering, 1(1), pp. 9-12.

Orhorhoro, E. K., Ikpeand, A. E. and Tamuno, R. I. (2016) 'Performance Analysis of Locally Design Plastic Crushing Machine for Domestic and Industrial Use in Nigeria', EJERS, European Journal of Engineering Research and Science, 1(2), pp. 26-30.

Pranoto, S. H. et al. (2020) 'Desain dan Analisis Mata Pisau Pencacah Untuk Pengolahan Sampah Plastik Menggunakan Finite Element Analysis', Infotekmesin, 11(2), pp. 147-152.

Pratama, J. and Mahardika, M. (2018) 'Finite element analysis to determine the stress distribution, displacement and safety factor on a microplate for the fractured jaw case', AIP Conference Proceedings, 1941, pp. 1-7.

Ramadhan, M. S., Mangalla, L. K. and Samhuddin (2018) 'Perancangan Dan Simulasi Frame Mobil Gokart', ENTHALPY-Jurnal Ilmiah Mahasiswa Teknik Mesin PERANCANGAN, 3(2), pp. 1-10.

Reddy, S. and Raju, T. (2018) 'Design and Development of mini plastic shredder machine', in IOP Conference Series: Materials Science and Engineering, pp. 1-6.

Rusdiyana, L. et al. (2016) 'Desain dan analisa pisau penghancur bonggol jagung sebagai bahan pakan ternak', Jurnal Energi Dan Manufaktur, 9(1), pp. 49-53.

Sitepu, G. and Hamzah (2016) 'Analisis Kekuatan Struktur " Tank Deck" Kapal LCT AT 117 M TNI AL', Jurnal Riset dan Teknologi Kelautan, 14(1), pp. 39-48.

Syamsiro, M., Hadiyanto, A. N. and Mufrodi, Z. (2016) 'Rancang Bangun Mesin Pencacah Plastik Sebagai Bahan Baku Mesin Pirolisis Skala Komunal', Jurnal Mekanika dan Sistem Termal (JMST), 1(2), pp. 43-48.

Wibawa, L. A. N. (2019) 'Desain dan Analisis Tegangan Alat Pengangkat Roket Kapasitas 10 Ton Menggunakan Metode Elemen
Hingga', Jurnal Energi dan Teknologi Manufaktur (JETM), 2(01), pp. 23-26.

Widjanarko (2015) 'Pemilihan Pisau Potong Mesin Perajang Limbah Plastik Dengan Metode Quality Function Deployment ( Qfd ) Dan Value Engineering ( Ve ) Sebagai Alternatif Peningkatan Taraf Hidup', Rotor, 8(April).

Yepes, C. P., Pelegrina, R. M. A. and Pertuz, M. G. J. (2018) 'Analysis by means of the finite element method of the blades of a PET shredder machine with variation of material and geometry', Contemporary Engineering Sciences, 11(83), pp. 4113-4120.

Yetri, Y., Sawir, H. and Hidayati, R. (2016) 'Rancang Bangun Mesin Pencacah Sampah Dan Limbah Plastik', in Seminar Nasional pengabdian kepada masyarakat, p. 375:385.

Yin, Z. and Xu, L. (2018) 'Finite element analysis and optimization design of paper cutter cutting blade based on ANSYS', in Proceedings International Conference on Robots and Intelligent System, pp. 475-478. 